International Journal of Business Management and Economic Review

Vol. 4, No. 03; 2021

ISSN: 2581-4664

\title{
THE EFFECT OF PRODUCT QUALITY, IMAGE CONGRUITY, AND CONTEXTUAL EXPERIENCE ON CUSTOMER PERCEIVED VALUE AND ITS IMPACT ON REPURCHASE INTENTIONS OF PACKAGED COFFEE CUSTOMERS: TESTING DIFFERENCES IN THE COFFEE SHOPS, SUPERMARKETS, AND SOUVENIR OUTLETS
}

\author{
*Mukhlis Yunus, Syafruddin Chan and Nery Nazwani Halim \\ Management Department, Universitas Syiah Kuala, Indonesia
}

http://doi.org/10.35409/IJBMER.2021.3267

\begin{abstract}
Consumer interest in buying packaged coffee powder, whether sold in coffee shops, supermarkets, or souvenir shops, can be viewed from a general review of consumer behavior. This study aims to see product quality, image congruity, and contextual experience on repurchase intentions both directly and through customer perceived value as a mediating variable. This study also aims to use comparative moderation analysis, which is comparing the frequency of consumers who shop at Coffee Shops, Supermarkets, and Souvenir Shops to see the level of responsiveness of these three groups, whether it is significantly different or not. The population in this study were all customers who bought coffee in coffee shops, supermarkets, and souvenir shops in Banda Aceh City. The probability sampling technique was used to determine the number of samples, where all members of the population have the same opportunity to be selected as a sample, namely as many as 150 people. The results showed that from the 7 direct hypotheses, 6 were accepted and 1 hypothesis was not significant, namely testing the effect of image congruity on repurchase intentions of packaged coffee customers because they had CR and $\mathrm{P}$ values that did not meet the requirements. The role of the customer perceived value variable in the three indirect effects also varies, namely acted as a partial mediator on the effect of product quality on re-purchase intentions through customer perceived value of packaged coffee customers, and the effect of contextual experience on re-purchase intentions through customer perceived value of packaged coffee customers, and acted as a full mediator on the effect of image congruity on re-purchase intentions through customer perceived value of packaged coffee customers. In the comparative model analysis that used the full model, the result proved there was a significant difference of the frequency of consumers who shop at the Coffee Shops, Supermarkets, and Souvenir Shops. However, in a path-by-path moderation comparison, the results vary from one path to another. These findings can be a reference for academic theory for future researchers. This tested model proved how customer perceived value acted as a partial mediator and a full mediator towards other variables. For future researchers, this tested model is expected to be combined with other variables such as consumer satisfaction and brand awareness.
\end{abstract}




\section{International Journal of Business Management and Economic Review}

Vol. 4, No. 03; 2021

ISSN: 2581-4664

Keyword: Product Quality, Image Congruity And Contextual Experience, Customer Perceived Value, Re-purchase Intention.

\section{INTRODUCTION}

High coffee production in Indonesia is an opportunity for business actors to process it into a coffee-based drink because coffee is a natural source of caffeine, a substance that can cause increased alertness and reduce fatigue. Consumption of coffee drinks in Indonesia is also expected to continue to increase every year because drinking coffee has become a habit or lifestyle. (Utami, Sadeli, \& Jie, 2016). Drinking coffee is also a trend in various circles of society in the world.

In Aceh, Indonesia, the trend of drinking coffee has developed from generation to generation, because Aceh has long been known as the best coffee-producing region, especially Arabica coffee which grows in the Gayo highlands. The trend of drinking coffee cannot be separated from the daily behavior of the Acehnese people. This can be seen from the number of coffee shops and packaged coffee brands that are scattered and easily found in various parts of the country which is nicknamed the city of Serambi Mekkah.

Nowadays there is indeed instant behavior among coffee fans. With the many activities they have to do, there are times when visiting a coffee shop to enjoy coffee is also constrained by time. So that many coffee connoisseurs have switched to buying packaged coffee for brewing at home. However, many also make this packaged coffee a souvenir. Both by those who visited Aceh and then brought home packaged coffee grounds as souvenirs, as well as by the Acehnese themselves who wanted to gift packaged coffee to relatives outside the region. Therefore, it is not surprising that currently packaged coffee is also sold in souvenir shops because they classify this packaged coffee product as a souvenir that should be brought home when visiting Aceh.

Due to the high attractiveness of the market, apart from being sold in coffee shops and souvenir shops, packaged coffee powder is also widely sold in supermarkets that are widely available in Banda Aceh. The packaged coffee product is one of the products sold in several coffee shops in the city of Banda Aceh. This packaged coffee is sold to fulfill the desires of consumers who like the taste of Aceh coffee so that consumers can buy and enjoy it anywhere more practically. This is evidenced by the large number of coffee shops that have sold packaged coffee products.

Consumer interest in buying packaged coffee powder, whether sold in coffee shops, supermarkets, or souvenir shops, can be viewed from a general review of consumer behavior. Because the pattern, desire, and intensity of consumers' desire to buy coffee powder in the packaging they are interested in is part of the consumer's behavior. (Alfanda, Ma'aruf, Darsono, \& Chan, 2018). Sometimes a consumer has high loyalty to coffee powder in certain packages, marked by repeated purchases (Kang, Tang, \& Bosselman, 2011). One of the reasons consumers do not want to buy back at The same supplier is due to the perceived value factor. He perceives the services provided by the supplier to be below his expectations (Widjiono \& Japarianto, 2015).

This research explores the role of customer contextual experience in repurchase intention because this aspect is considered important in increasing repurchase intention for certain products, including packaged coffee. In addition, this study is also different because it uses 


\section{International Journal of Business Management and Economic Review}

Vol. 4, No. 03; 2021

ISSN: 2581-4664

comparative moderation analysis, which is comparing consumers who frequently shop at Coffee Shops, Supermarkets, and Souvenir Shops to see the level of responsiveness of these three groups, whether it is significantly different or not. This analysis is useful for packaged coffee producers in using their distribution channels, which distribution channels are prioritized so that the repurchase intention of packaged coffee customers can increase.

\section{LITERATURE REVIEW}

\section{Repurchase Intention}

According to Tsai in (Puspitasari, Rahadhini, \& Saputra, 2017), repurchasing is a motivational level for a consumer to repeat the buying behavior of a product. One of them is indicated by the use of a brand from a sustainable product. Repurchasing according to Peter \& Olson in (Oetomo \& Nugraheni, 2012) is a purchase activity that is carried out more than once or several times. The satisfaction obtained by a consumer can encourage someone to make repeat purchases, and become loyal to the product or loyal to the store where he bought the item so that consumers can tell good things to others. (Heriyana, Ma'ruf, Lubis, \& Chan, 2019)

\section{Customer Perceived Value}

The concept of customer value describes a company's customers, considers what they want, and believes they benefit from a product (Yunus \& Sijabat, 2021). (Hume \& Mort, 2010) saw the need for cross-functional operations in a company, namely marketing, operations, and human resources as prerequisites for managing customer value. The elements of managing customer relationships and managing perceived value are the tasks of the marketing function. The element of increasing the ability of employees as value creators is the task of human resource management, while the element of improving quality performance is the task of the operations function (Duan, Jung, \& Park, 2012).

\section{Product quality}

According to (Jahanshahi, Gashti, Mirdamadi, Nawaser, \& Khaksar, 2011) stated that the product meets customer expectations, so the customer will be happy and think that the product has acceptable quality or even has high product quality. According to (Kotler \& Armstrong, 2017), "Products are anything that can be offered to the market to attract attention, acquisition, use, or consumption that can satisfy a desire or need". They also said, "Products are everything that is offered to the market to meet wants or needs, including physical goods, services, experiences, events, people, places, properties, organizations, information, and ideas".

\section{Image congruity}

Everyone has a distinctive self-image. This distinctive self-image is the result of the development of the individual's background and experience. Image is one of the bases used by consumers to determine how suitable their personality is to a particular retail image (Lindquist \& Sirgy, 2009). According to (Opiri, 2015) self-image congruity is referred to as a cognitive fit between a customer's self-concept, and a product, service, or brand image. Customers develop their perceptions based on stereotypical images typical of users of a particular product, brand, or service. 
Vol. 4, No. 03; 2021

ISSN: 2581-4664

\section{Contextual Experience}

(Yu \& Fang, 2009) defined customer experience as an internal and subjective response that consumers have to direct or indirect contact with a company. Direct contact generally occurs at the time of purchase, use, and service. Indirect contact includes unplanned meetings with representations of products, services, or company brands in the form of recommendations or criticisms, advertisements, news reports, reviews, and so on.

\section{Research paradigm}

The paradigm or relationship between concepts (variables) in this study can be illustrated in Figure 2.1 below.

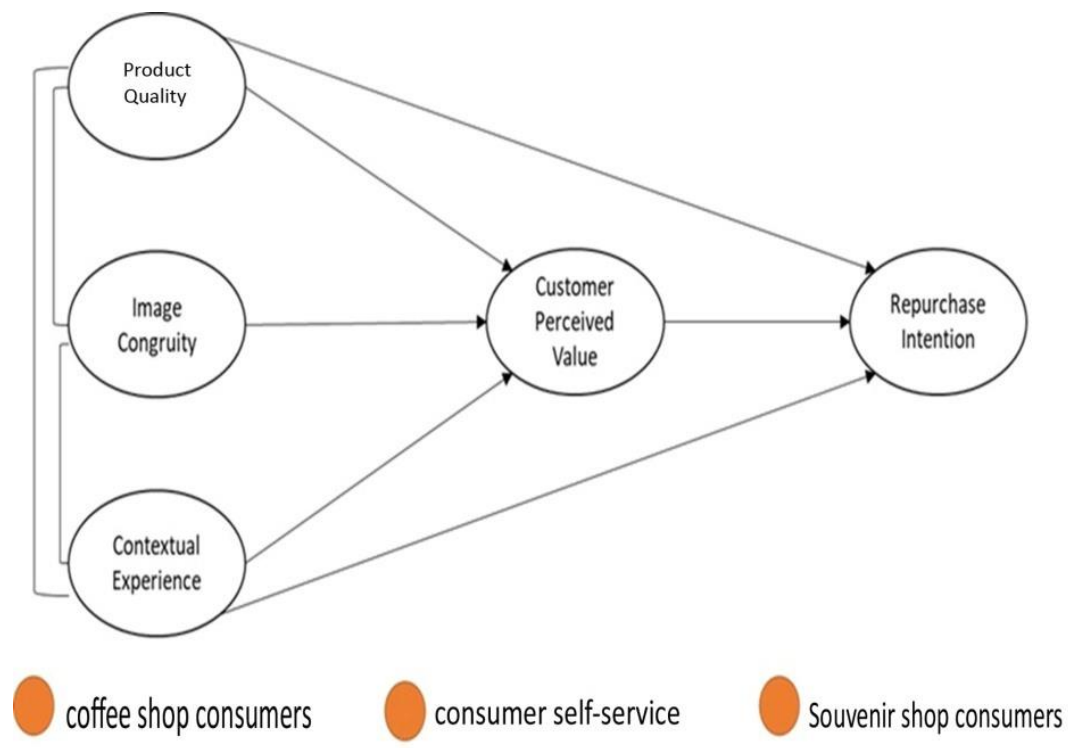

Figure 1 Research Paradigm

\section{Hypothesis}

Based on the phenomena and from the theoretical foundations that have been stated previously, some of the research hypotheses developed in this study are:

H1 : There is an effect of product quality on customer perceived value in packaged coffee customers

$\mathrm{H} 2$ : There is an effect of image congruity on customer perceived value in packaged coffee customers

$\mathrm{H} 3$ : There is an effect of contextual experience on customer perceived value in packaged coffee customers

H4 : There is an effect of product quality on re-purchase intentions of packaged coffee customers

H5 : There is an effect of image congruity on re-purchase intentions of packaged coffee customers 


\section{International Journal of Business Management and Economic Review}

Vol. 4, No. 03; 2021

ISSN: 2581-4664

H6 : There is an effect of contextual experience on re-purchase intentions of packaged coffee customers

H7 : There is an effect of customer perceived value on re-purchase intentions of packaged coffee customers

H8 : There is an effect of product quality on re-purchase intentions through customer perceived value of packaged coffee customers

H9 : There is an effect of image congruity on re-purchase intentions through customer perceived value of packaged coffee customers

H10: There is an effect of contextual experience on re-purchase intentions through customer perceived value of packaged coffee customers

H11: There is a significant difference between groups of packaged coffee buyers in coffee shops, supermarkets, and souvenir shops in the full model of this study.

\section{METHOD}

\section{Location and Object of Research}

The location of this research was conducted at coffee shops, supermarkets, and souvenir shops in the city of Banda Aceh. Research survey of customers who buy coffee in coffee shops, supermarkets, and souvenir shops.

\section{Sampling}

The population in this study is infinite, namely packaged coffee buyers in Banda Aceh, which consists of buyers in coffee shops, supermarkets, and souvenir shops. This study uses a sampling technique with a method using probability sampling techniques where all members of the population have the same opportunity to be selected as a sample. The number of samples that are feasible after the Slovin calculation is 150 people.

\section{Data analysis method}

Data processing obtained in the field is done by using equation modeling techniques, namely multivariate statistical analysis techniques to be able to analyze not only the influence between variables but also the relationship between variables and their respective indicators. The criteria for acceptance of Ha are Critical Ratio (CR) $>1.96$ and the value of Probability $(\mathrm{P})<0.05$.

\section{RESULT}

\section{Loading Factor with measurement test}

Testing the validity of loading factors can be seen in the following figure and Table: 
Vol. 4, No. 03; 2021

ISSN: 2581-4664

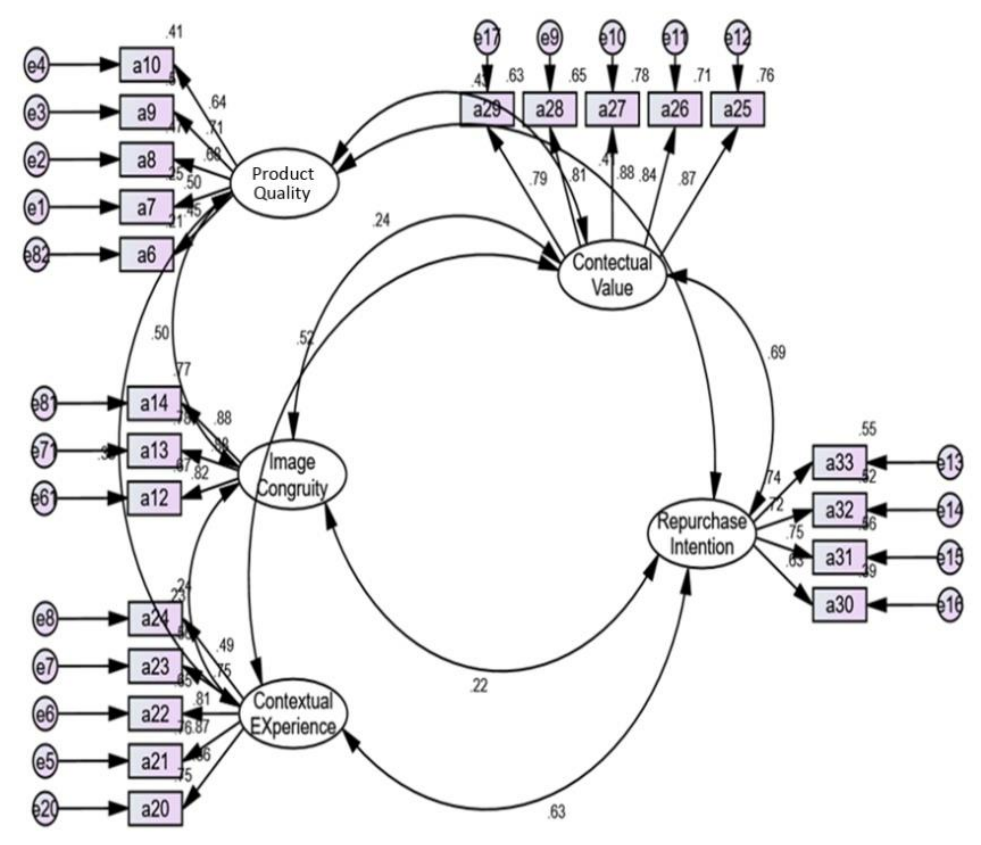

Figure 2 Loading Factor

Measurement test results indicate that several indicators of the research variables have a loading factor value below 0.5 . The following table shows the results of the net measurement test which can later be included in structural testing.

Table 1. Loading Factor

\begin{tabular}{|l|l|l|l|l|}
\hline No. & Indicator & & Variable & Estimate \\
\hline 1 & a7 & $<---$ & Product quality & .501 \\
\hline 2 & a8 & $<---$ & Product quality & .683 \\
\hline 3 & a9 & $<---$ & Product quality & .713 \\
\hline 4 & a10 & $<---$ & Product quality & .642 \\
\hline 5 & a12 & $<---$ & Image_Congruity & .818 \\
\hline 6 & a13 & $<---$ & Image_Congruity & .883 \\
\hline 7 & a14 & $<---$ & Image_Congruity & .879 \\
\hline 8 & a28 & $<---$ & Customer Perceived Value & .808 \\
\hline 9 & a27 & $<---$ & Customer Perceived Value & .883 \\
\hline 10 & a26 & $<---$ & Customer Perceived Value & .842 \\
\hline 11 & a25 & $<---$ & Customer Perceived Value & .875 \\
\hline 12 & a33 & $<---$ & Repurchase_Intention & .740 \\
\hline 13 & a32 & $<---$ & Repurchase_Intention & .719 \\
\hline
\end{tabular}




\section{International Journal of Business Management and Economic Review}

Vol. 4, No. 03; 2021

ISSN: 2581-4664

\begin{tabular}{|l|l|l|l|l|}
\hline \hline No. & Indicator & & Variable & Estimate \\
\hline 14 & a31 & K--- & Repurchase_Intention & .746 \\
\hline 15 & a30 & $<---$ & Repurchase_Intention & .625 \\
\hline 16 & a29 & K--- & Contextual_Experience & .795 \\
\hline 17 & a221 & K--- & Contextual_Experience & .871 \\
\hline 18 & a22 & $<---$ & Contextual_Experience & .808 \\
\hline 19 & a23 & $<---$ & Contextual_Experience & .750 \\
\hline 20 & a24 & $<---$ & Contextual_Experience & .488 \\
\hline 21 & a20 & $<---$ & Contextual_Experience & .864 \\
\hline 22 & a6 & $<---$ & Product quality & .455 \\
\hline
\end{tabular}

Table 1 shows the loading factor of all the indicators in the model and has met the requirements for further processing because it has a loading factor value $>0.5$.

Table 2. The goodness of Fit Criteria Table

\begin{tabular}{|l|l|l|l|}
\hline criteria Size Index & Cut-off Value & Analysis Results & Model Evaluation \\
\hline Chi-Square & Small expected & 386,707 & Fit \\
\hline CMIN / DF & CMIN / DF $<2$ & 1,963 & Fit \\
\hline GFI & $\geq 0.90$ & 0.908 & Fit \\
\hline AGFI & $\geq 0.90$ & 0.869 & Good \\
\hline PGFI & $0-1$ & 0.789 & Fit \\
\hline RMSEA & $<0.08$ & 0.072 & Fit \\
\hline
\end{tabular}

\section{Structural Analysis for Direct Hypothesis testing (Direct Testing)}

The results of the structural testing carried out have produced the information needed to answer the previously built hypothesis whether it is proven or not. Figure 3 below illustrates the influence between variables: 
Vol. 4, No. 03; 2021

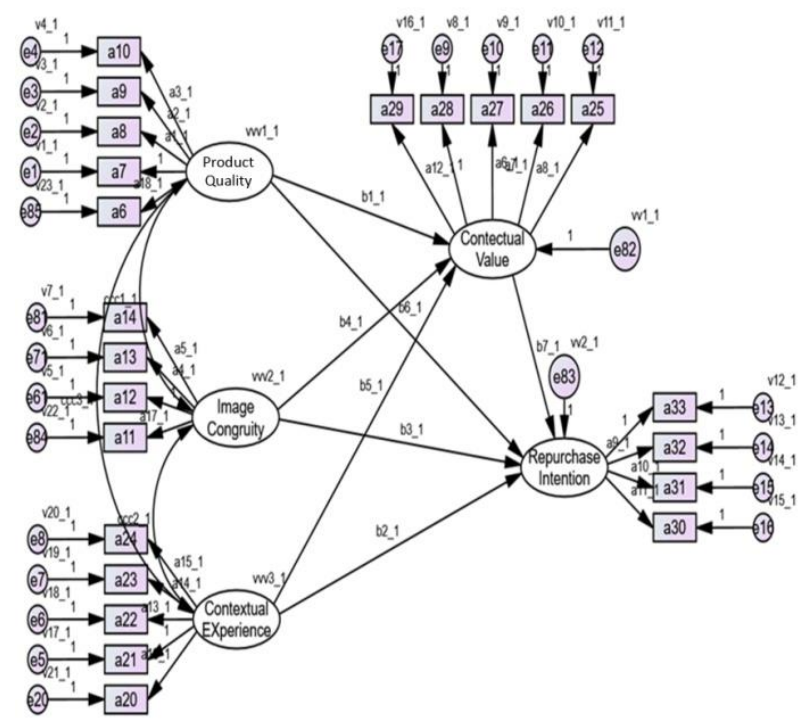

Figure 3. Structural Equation Model

Based on Figure 3, it can be explained that the influence of each variable, namely product quality, image congruity and contextual experience, customer perceived value, and repurchase intention. An overview of all hypothesis testing along with the results can be seen in Table 3 below:

\section{Table 3. Direct Hypothesis Result}

\begin{tabular}{|c|l|l|l|l|}
\hline No. & Hypothesis & $\begin{array}{l}\text { CR Cut off } \\
\mathbf{1 . 9 6}\end{array}$ & $\begin{array}{l}\text { P-Value Cut off } \\
\mathbf{0 . 0 5}\end{array}$ & $\begin{array}{l}\text { Informati } \\
\text { on }\end{array}$ \\
\hline 1 & $\begin{array}{l}\text { There is an Influence of Product } \\
\text { Quality on Customer Perceived } \\
\text { Value }\end{array}$ & 2,928 & 0.003 & accepted \\
\hline 2 & $\begin{array}{l}\text { There is an influence of Image } \\
\text { Congruity on Customer Perceived } \\
\text { Value }\end{array}$ & 5,076 & $* * * *$ & accepted \\
\hline 3 & $\begin{array}{l}\text { There is an Influence of } \\
\text { Contextual Experience on } \\
\text { Customer Perceived Value }\end{array}$ & 5,075 & accepted \\
\hline 4 & $\begin{array}{l}\text { There is an Influence of } \\
\text { Contextual Experience on } \\
\text { Repurchase Intention }\end{array}$ & 6,523 & $* * * *$ & accepted \\
\hline 5 & $\begin{array}{l}\text { There is an Influence of Product } \\
\text { Quality on Repurchase Intention }\end{array}$ & 7,747 & $* * * *$ & accepted \\
\hline 6 & $\begin{array}{l}\text { There is an influence of Image } \\
\text { Congruity on Repurchase } \\
\text { Intention - }\end{array}$ & $-1,128$ & .259 & rejected \\
\hline
\end{tabular}




\section{International Journal of Business Management and Economic Review}

Vol. 4, No. 03; 2021

ISSN: 2581-4664

\begin{tabular}{|c|l|l|l|l|l|}
\hline \hline No. & Hypothesis & $\begin{array}{l}\text { CR Cut off }> \\
\mathbf{1 . 9 6}\end{array}$ & $\begin{array}{l}\text { P-Value Cut off } \\
\mathbf{< 0 . 0 5}\end{array}$ & $\begin{array}{l}\text { Informati } \\
\text { on }\end{array}$ \\
\hline 7 & $\begin{array}{l}\text { There is an Influence of Customer } \\
\text { Perceived Value on Repurchase } \\
\text { Intention }\end{array}$ & 7,745 & $* * *$ & accepted \\
\hline
\end{tabular}

It can be seen from the 7 direct hypotheses that there is 1 (one) hypothesis that is not significant or rejected, namely testing the effect of Image Congruity on Repurchase Intention because it has a CR value of -1.128 and a $P$ value of 0.259 which does not meet the minimum requirements of the accepted hypothesis. In other words, another independent variable, namely Image Congruity, has the effect of increasing the dependent variable, namely Repurchase Intention, as long as the independent variable can be improved by the leadership or management of the coffee shop outlet.

\section{Direct and Indirect Influence}

The following is the conclusion of the indirect hypothesis, namely the effect of product quality, image congruity, and contextual experience on re-purchase intentions of packaged coffee buyers in Banda Aceh, which consists of buyers at coffee shops, supermarkets, and souvenir shops through customer perceived value as shown in Table 4 below:

Table 4. Indirect Hypothesis Result

\begin{tabular}{|l|l|l|l|l|l|}
\hline No. & Indirect Hypothesis & $\begin{array}{l}\text { P-Value } \\
\mathbf{< 0 . 0 5}\end{array}$ & Beta & $\begin{array}{l}\text { Informati } \\
\text { on }\end{array}$ & $\begin{array}{l}\text { Role } \\
\text { Mediation }\end{array}$ \\
\hline H8 & $\begin{array}{l}\text { The Effect of Product Quality on } \\
\text { Repurchase Intention through } \\
\text { customer perceived value }\end{array}$ & 0.006 & $8.7 \%$ & Accepted & Partial Mediating \\
\hline H9 & $\begin{array}{l}\text { The effect of image congruity on } \\
\text { Repurchase Intention through } \\
\text { customer perceived value }\end{array}$ & 0.002 & $9.4 \%$ & accepted & Full Mediating \\
\hline H10 & $\begin{array}{l}\text { The effect of contextual } \\
\text { experience on Repurchase } \\
\text { Intention through customer } \\
\text { perceived value }\end{array}$ & 0.002 & $7.8 \%$ & Accepted & Partial Mediating \\
\hline
\end{tabular}

There are 3 indirect effects tested, namely the effect of product quality on the re-purchase intentions through customer perceived value in packaged coffee customers, the effect of image congruity on re-purchase intentions through customer perceived value on packaged coffee customers, and the effect of contextual experience on re-purchase intentions through customer perceived value of packaged coffee customers. All three show a significant effect. The role of the customer variable perceived value in these three indirect effects also varies, namely partial mediator on the $\mathrm{H} 8$ and $\mathrm{H} 10$ and full mediator on the $\mathrm{H} 9$. 


\section{International Journal of Business Management and Economic Review}

Vol. 4, No. 03; 2021

ISSN: 2581-4664

\section{Table 5. Moderation Hypothesis Result}

\begin{tabular}{|r|l|l|l|}
\hline $\begin{array}{l}\text { No } \\
\cdot\end{array}$ & Hypothesis & P-value & $\begin{array}{l}\text { Informatio } \\
\text { n }\end{array}$ \\
\hline 1 & Full Model & .000 & accepted \\
\hline 2 & Product Quality to Customer perceived value & .064 & Rejected \\
\hline 3 & Image congruity to Customer perceived value & .537 & Rejected \\
\hline 4 & Consumer Contextual Experience to Customer Perceived Value & .409 & Rejected \\
\hline 5 & Product Quality to Repurchase Intention & .007 & accepted \\
\hline 7 & Contextual Experience to Repurchase Intention & 0.010 & accepted \\
\hline 8 & Customer perceived value Against Repurchase Intention & 0.086 & Rejected \\
\hline
\end{tabular}

In moderation testing of consumer groups who buy packaged coffee products at coffee shops (H11), supermarkets, and souvenir shops, in the Full model testing, there are real differences. However, in a path by path moderation comparison, the results vary from one path to another.

\section{CONCLUSION}

The result shows that from the 7 hypotheses tested, namely the effect of product quality on customer perceived value in packaged coffee customers (H1), the effect of image congruity on customer perceived value in packaged coffee customers (H2), the effect of contextual experience on customer perceived value in packaged coffee customers (H3), the effect of product quality on re-purchase intentions in packaged coffee customers (H4), the effect of image congruity on repurchase intentions in the packaged coffee customers (H5), the effect of contextual experience on re-purchase intentions in packaged coffee customers (H6) and the effect of the customer perceived value on re-purchase intentions in packaged coffee customers (H7), there is one hypothesis that is not supported, namely there is an image effect of image congruity on repurchase intentions in packaged coffee customers (H5). Thus the independent variables that are considered to have contributed to the increase in consumer re-purchase intentions are the Quality of Coffee Ground Products, Customer Perceived Value, and Contextual Experiences. There are 3 indirect effects tested, namely the effect of product quality on re-purchase intentions through customer perceived value in packaged coffee customers (H8), the effect of image congruity on re-purchase intentions through customer perceived value on packaged coffee customers (H9), and the effect of contextual experience on re-purchase intentions through customers perceived value to packaged coffee customers (H10). All three show a significant effect. The role of the customer variable perceived value in these three indirect effects also varies, namely partial mediator on the $\mathrm{H} 8$ and $\mathrm{H} 10$ and full mediator on the $\mathrm{H} 9$.

For H11, in moderation testing of consumer groups who buy packaged coffee products at coffee shops, supermarkets, and souvenir shops, in the Full Model, there are real differences. However, in a path by path moderation comparison, the results vary from one path to another. Based on the findings, several recommendations can be mapped, as follows. The task of the leader or decision-maker on packaged ground coffee is to take advantage of this information in seeing which group is more responsive in responding to the initiation of a marketing strategy that 


\section{International Journal of Business Management and Economic Review}

Vol. 4, No. 03; 2021

ISSN: 2581-4664

is carried out both for an increase in product quality, an increase in image and an increase in consumer experience in consuming packaged coffee products. this. The highest coefficient number must be the concern of managerial parties. For example, the effect of product quality on repurchase intention is the most responsive group of consumers who buy at coffee shops compared to those who buy at supermarkets or souvenir shops. Conversely, in responding to the perceived value policy towards repurchase intention, it turns out that the souvenir shop group is more aggressive than the coffee shop and supermarket groups.

\section{REFERENCES}

Alfanda, R., Ma'aruf, J. J., Darsono, N., \& Chan, S. (2018). Celebrity Endorsement as Moderating Variable on the Relationship between Loyalty and Corporate Credibility of Travel Companies in Aceh. International Journal of Contemporary Research and Review, 9(4), 20726-20734. https://doi.org/https://doi.org/10.15520/ijcrr/2018/9/04/500

Duan, L.-N., Jung, C.-H., \& Park, K.-H. (2012). The Effects of Perceived Risk Affecting Perceived Value and Repurchase Intention in Electronic Commerce Environment. Journal of Digital Convergence, 10(3), 13-21. https://doi.org/https://doi.org/10.14400/JDPM.2012.10.3.013

Heriyana, Ma'ruf, J. J., Lubis, P. H., \& Chan, S. (2019). The Effect of Perceived Risk on Repurchase Intention of Online Shopping Mediated By Customer Satisfaction in Indonesia. The First Economics, Law, Education and Humanities International Conference (The First ELEHIC), 340-348. https://doi.org/10.18502/kss.v3i14.4320

Hume, M., \& Mort, G. S. (2010). The consequence of appraisal emotion, service quality, perceived value and customer satisfaction on repurchase intent in the performing arts. Journal of Services Marketing, $24(2), \quad 170-182$. https://doi.org/https://doi.org/10.1108/08876041011031136

Jahanshahi, A. A., Gashti, M. A. H., Mirdamadi, S. A., Nawaser, K., \& Khaksar, S. M. S. (2011). Study the Effects of Customer Service and Product Quality on Customer Satisfaction and Loyalty. International Journal of Humanities and Social Science, 1(7), 253-260.

Kang, J., Tang, L., \& Bosselman, R. (2011). Changes of Coffee Consumption Behaviors in Korea: The Effects of Image Congruity Toward Brand Name Coffee Shops on Customer Attitude and Repurchase Intention. Proceedings of the 16th Annual Graduate Education \& Graduate Student Research Conference in Hospitality \& Tourism, 1-14. Houston, Texas: Iowa State University Digital Repository.

Kotler, P., \& Armstrong, G. (2017). Principles of Marketing (17th ed.). London: Pearson.

Lindquist, J., \& Sirgy, M. J. (2009). Shopper, Buyer, and Consumer Behavior: Theory, Marketing Applications, and Public Policy Implications. Cincinnati, $\mathrm{OH}$ : Atomic Dog/Cengage Learning.

Oetomo, R. A., \& Nugraheni, R. (2012). Analisis Pengaruh Keragaman Menu, Persepsi Harga dan Lokasi Terhadap Minat Beli Ulang Konsumen (Studi Pada Restoran Waroeng Taman Singosari Semarang). DeRema Jurnal Manajemen, 2(1).

Opiri, J. A. (2015). The Influence of Self-image Congruity on Perceived Value and Brand Loyalty Concerning Sportswear. Louisiana State University.

Puspitasari, F., Rahadhini, M. D., \& Saputra, S. D. (2017). Pengaruh Pemasaran Relasional Dan Nilai Pelanggan Terhadap Loyalitas Pelanggan Dengan Kepuasan Sebagai Variabel 
Vol. 4, No. 03; 2021

ISSN: 2581-4664

Moderasi. Jurnal Ekonomi Dan Kewirausahaan, 17(3), 498-507.

Utami, H. N., Sadeli, A. hermita, \& Jie, F. (2016). The Impact of Customer Value Towards Customer Loyalty of Ready to Drink Tea Bottled. Conference: International Symposium on Logistics (21st ISL), 393-401. Taiwan: Kaohsiung.

Widjiono, L. M., \& Japarianto, E. (2015). Analisa Pengaruh Self Image Congruity, Retail Service Quality, Dan Customer Perceived Service Quality Terhadap Repurchase Intention Dengan Customer Satisfaction Sebagai Variabel Intervening Di Broadway Barbershop Surabaya. Jurnal Manajemen Pemasaran, 9(1), 35-42. https://doi.org/https://doi.org/10.9744/pemasaran.9.1.35-42

Yu, H., \& Fang, W. (2009). Relative impacts from product quality, service quality, and experience quality on customer perceived value and intention to shop for the coffee shop market. Total Quality Management and Business Excellence, 20(11), 1273-1285. https://doi.org/10.1080/14783360802351587

Yunus, M., \& Sijabat, F. N. (2021). A Review on Blue Ocean Strategy Effect on Competitive Advantage and Firm Performance. Academy of Strategic Management Journal, 20(1), 1-10. 